\title{
密着したブロックゲージの実質接触面積の 測定とその密着力に及ぼす影響*
}

\author{
加藤敬** 桜 井, 好 正** \\ Measurement of Real Contact Area of Wrung Gauge Block \\ and Effect of the Area on Wringing Force \\ Takashi Kato, Yoshimasa SAKuraI
}

This paper describes the experimental result on the relation between real contact area and wringing force of gauge block. The real contact area of wrung gauge blocks is measured by means of the application of the total reflection method which was already developed by $Y$. Sakurai, one of the authors. A polarized parallel light beam is projected on the hypotenuse plane of a rectangular glass prism beneath which a gauge block is wrung, and polarizers are adjusted so as to intercept the reflecting light from the metal surface. Thus, the contact parts are observed as dark images in light back ground. The total contact area is measured by a photoelectric method. The wringing force is measured by torque to make slide for wringing off the gauge block from the plate. It is clarified that the real contact area is approximately in proportion to the wringing force. Moreover, the measuring error of the contact area caused by an obscurity of the images accompanied by total reflection is discussed.

\section{1. 緒言}

現在のブロックゲージの密着の定義はきわめて概念的 であり，ガラス定盤を用いてブロックゲージを光波干渉 測定するさいの密着の良否は, 素手による手ごたえや定 盤裏面よりの視覚などにより判定されている. また実際 の密着作業でも時には裸眼で良い密着と判断されても密 着力の弱いものがあったり, またその逆の場合も起こ כ.

このような判定基準のあいまいさや複雑な挙動を明ら ふ沉方立場から，なでにいくつかの研究が行われてい る. 筆者もブロックゲージをガラス定盤上に密着した場 合の密着力（密着トルク）とブロックゲージの寸法との 関䋆そ調べ，密着を繰返した場合，密着力が大きい時ほ ご二つの密着面がより接近することを知り，これを報 告12)した.

ブロックゲージの面のおうとつの状態から考えれば, 密着の場合, 二つの面の重なった全面にわたって完全に 接触しているとは考えられず, 数多くのきわめて小さい 面で離散的に接触しているものと思われる. 密着力はこ の実質的な接触面積の大きさに関係すると思われるが， いままでブロックゲージの密着がこのような観点から調

* 原稿受付 昭和 51 年 10 月 8 日. 昭和 47 年度精機学会秋 季大会学術講演会（昭和 47 年 10 月 30 日）にて発表.

** 正会員 計量研究所 (東京都板橋区加賀 1-10-4)
ベられたことがない，本報はそれらの関係を実験的に調 ベたものである.

\section{2. 接触面積の測定装置}

接触面積の測定には電気抵抗を使った方法3)もあるが, ここでは図 1 に示すような全反射を応用した測定法を用 いることにした。 これは以前に全反射式仕上面検査機4) として開発され，今回その一部分を改良して利用したも のである.この方法にも後で述べるようなかなりの誤差 が予想されるが，接触面積に対する密着力の大きさの関 係を知るにはこの方法で十分であると考えられる。

直流安定化電源により点灯された白熱球からの光は, コリメータで平行光線となり, 偏光板 (a) と 4 分の 1 波 長板を通り，入射角 $\alpha$ で直角プリズムの斜面に入射し全 反射する. 反射光は偏光板 (b) を通り，さらに顕微鏡に 入射する、いまプリズムの斜面に図のように金属面（た とえば鋼球）が接触すると，その部分だけが金属面の反 射となる．ここで金属面からの反射光が直線偏光になる

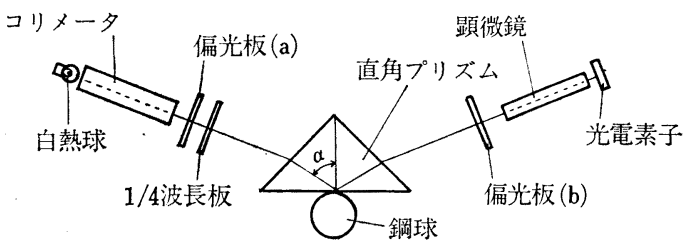

図 1 接触面積測定装置の光学系 
906

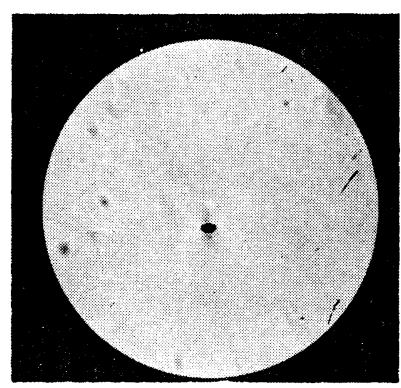

図 2 鋼球が接触した時 の視野

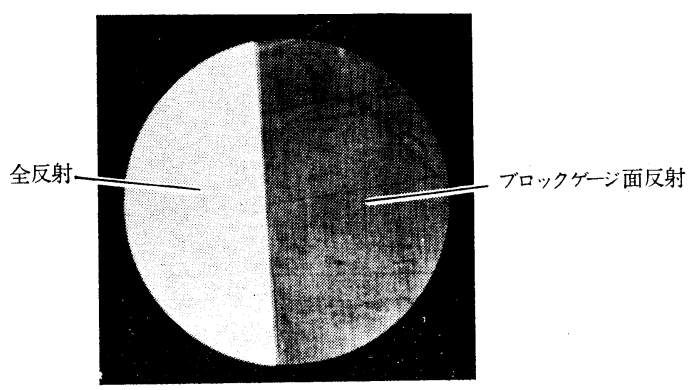

図 3 密着したブロックゲージ面の反射と全反射との対比 ように偏光板 (a) と 4 分の 1 波長板を調整し, さらにこ の直線偏光が遮断されるように偏光板 (b) の角度を調整 する．この場合，金属面が接触しない部分すなわちガラ 又面からの全反射光は，一般に楕円偏光となり偏光板 （b）を通過する。したがって鋼球が接触している場合， 顕微鏡の視野では図 2 のように明るい背景に鋼球の接触 部分の暗黑の像が見える、顕微鏡の実像が結ぶ面に光電 素子を置き，その出力を記録する，光電素子はシリコン 光検出ダイオードを用い, 特にタングステンランプと分 光感度特性が良く似たるのを選び，且つ大力に対方る起 電力特性の直線部分定使用した。

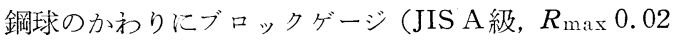
$\mu \mathrm{m}$ 程度)を密着した場合には，図 3 に示すように全面 に多数の微小な暗い接触部分が散在したような視野とな る. 図の視野が円形であるのは顥微鏡の対物レンズの前 方に置かれた円形絞りによるもので，物体面で直径約 $4 \mathrm{~mm}$ に相当する。この範囲内で焦点むらは活とんど認 められなかった。

いま, 視野全体からの光の強度を $I_{x}$, 試料面がガラス 面に全く接触しないときの光の強度を $I_{n}$ とす机ば，全 面化接触するときは視野は全く暗くなるはずであるか ら, 試料の見かけの接触面積に対する実質的な接触面積 の比（以下接触面積比と呼ぶことにする）は

$$
\left(I_{n}-I_{x}\right) / I_{n}
$$

で与えられる，全面で接触した状態で完全に暗くなるか どうかを調べるためには，そのような接触状態を作り出

\section{敬, 桜井好正}

す必要がある.しかし巨視的にはもとより微視的にも全 面で接触できるような平面を作ることはほとんど不可能 なので，ここでは屈折率がガラスとほぼ等しいセダー油 を測定面に塗布し，二つの面の間隙をセダー油で満たす ように密着した。このような状態は光学的には全面で接 触した状態とほぼ同一であり，上記の光学系で観測すれ ば全面暗くなるはずである。しかし実際には光学系の〉 レヤなどのためと思わ礼るが光電素子の出力はゼ口とは ならなかった。したがってここでは全面接触した状態は セダー油で満たして得られた値で表した。

この実験装置では光源と試料の位置が固定され, 顕微 鏡だけが図 4 亿示すように試料を密着したプリズムの稜 線と平行に移動し，測定点を変えられる構造になってい る. したがってこの場合, 照明むらの影響を避けるため 顕微鏡の位置に応じて得られた值を基に補正值を決る た.

この測定法には原理的にある程度の䛊差が含ま礼るこ 之が知られている4)。すなわち試料面同士が完全に接触 しなくても波長の数分の 1 程度まで接近すれば金属面反 射の傾向があらわれ，面が接近するに従ってこの傾向が ますます強まる現象がある。したがって接触面は実際汇 はやや大きく測定されるはずである。このような䛊差い 入射角が大きい程小さい，肉腿観測の場合にはすでにこ の大きさが測定されており，入射角が比較的大きく旦つ 接触面を観測しやすい5 55 ～60 の場合，約 $0.02 \mu \mathrm{m}$ まで 接近すれば接触しているように見光ることが知られてい る4)万).ささらにこの測定法で $0.01 \mu \mathrm{m}$ オーダの 2 面の距 離を論ずる場合, 微視的な表面の定義の問題と之もに洗 浄を丁寧に行っても微視的谷間などに油が残留したり水 蒸気が付着したりし，これが接触面積比に影響を与える ことが推定される，その意味で本来の金属接触ではない かもしれないが，この場合本来の金属接触が増えれば゙油 などの影響も增えるはずであるから，実験結果は十分に 接触面積の目安になると考えられる.

\section{3. 接触面 皘 比}

前章で述べた方法に上れば接触面積が穾際より大きく 観測されるが，その程度は入射角が大きくな礼ばなる程 小さくなり，真実の面積に近づくことはすでにのべた。 そこで図 4 に示すようにブロックゲージの長手方向が直 角プリズムの稜線と平行且つ斜面の中央に位置するよう に密着し, 入射角を $45 \sim 60^{\circ}$ の範囲で変えて接触面積比 を測定した，測定試料はJIS A 級で，製作者，製作年の 組合せの異なる 7 種類のブロックゲージであり，このう ち代表的な 3 試料の結果を図 5 亿示す。プロットされた 


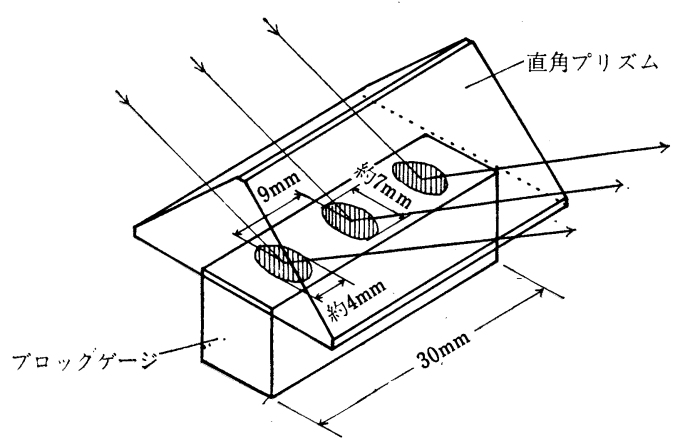

図 4 密着方法と測定位置

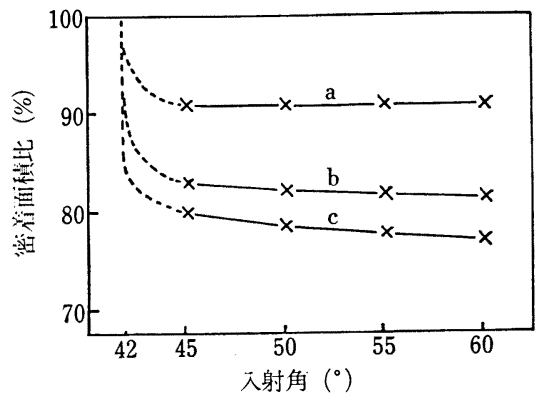

図 5 泌着面積比の入射角による影響

值はブロックダージ面の中央および両端の 3 か所の平均 值である. 入射角の増加とともに接触面積比は減少し一 定值に収束する傾向があり，この值が真の接触面積比と 考えることができる. 接触面積比が小さいもの程収束が 悪い傾向を示すが， 入射角 $55^{\circ}$ を選べば詋差はきわめて 小さいことがわかる：この実験結果も残留油の影響を受 棌ているはずで問題はあるが，以後の実験では入射角を $55^{\circ}$ とすることにした. この角度で光電素子がとらえる 顕微鏡視野での有効面積は, 図 4 にも示したようにブロ ックゲージ面上で約 $7 \times 4 \mathrm{~mm}$ の楕円となる．また， 7 種 類の試料の $R_{\max }$, 単位長さ当たりの山数, 平面度を求 め, それぞれ接触面積比との関係を調べたが，明快な結 果は得られなかった. しかし接触面積比は密着トルクと 泳比例する傾向がみられた。

なお，この測定結果による接触面積比の反復のばらつ きは $2 \%$ 以内である。

\section{4. 密着トルクの測定}

密着力の測定は図 6 に示す密着トルク測定装置1）利 用した.これは密着している直角プリズムとブロックゲ ージを，図に示すようにそれぞれの取付部のみぞにはめ 込む方法でセットし，プリズム取付部を回転させて密着 がはずれた瞬間のトルク（以下密着トルク）を，りん青 銅棒に設置したひずみゲージで検出, 記録するものであ

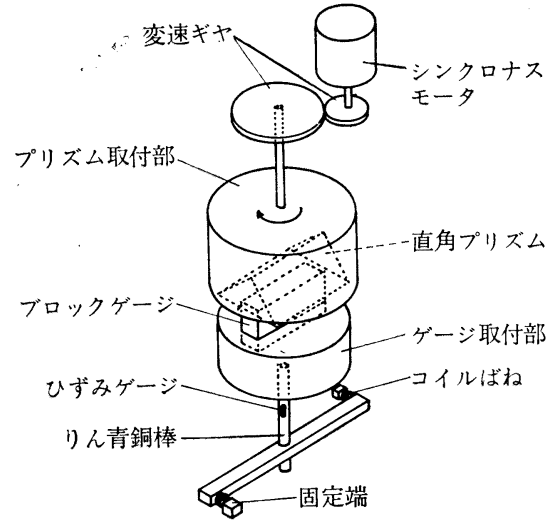

図 6 密着トルク測定装置の構造

る.この測定装置の反復によるばらつきは $0.5 \%$ 以内で ある・

\section{5. 実 験 試 料}

ブロックゲージは鋼製で寸法は $10 \mathrm{~mm}$ ，測定面にき ずなどが少なく，製作者，製作年の 異なる 4 面を選ん だ. 直角プリズムは 2 個使用したが，いずれも密着面の 平面度 $0.03 \mu \mathrm{m}$ ，材質 BK-7 でほぼ同一の性能のもので ある。

\section{6. 実験条件および手順}

1 反復の測定は次の条件および手順に沿って行った.

（1）試料の密着面を石油ベンジンなどを使用して良く 洗浄する (日常の光波干渉測定の際とほぼ同じ).

（2）密着トルク測定装置を利用して垂直荷重 $2 \mathrm{kgf} を$ かけ，図4 に示すような位置に密着する.

(3) 約 5 min の温度ならしの後, 密着面積比を測る.

(4) 密着トルクを測る.

密着状態は密着ごとに異なるので 1 反復の測定を各試 料について 10 回以上行い, 測定值を 統計的に 処理して 接触面積比々密着トルクの関係を求めた.

なお，既報1)の結果では, 密着トルクの大きい程 2 面 の間隙が狭くなり, ブロックゲージの光波干渉測定を行 う場合 $10 \mathrm{kgf} \cdot \mathrm{cm}$ 以上の密着トルクがのぞましく, $5 \mathrm{kgf} \cdot \mathrm{cm}$ 以下は測定に不適当な密着である. しかし, こ こでは実験的な興味として $5 \mathrm{kgf} \cdot \mathrm{cm}$ 以下の密着トルク も含めて評価した。

\section{7. 実験結果および検討}

図 7 (a)〜 (d) は実験結果である. 横軸に密着トルク， 縦軸に接触面積比をとり，4面それぞれについて行った 反復測定データをプロットしたものである，実線は，最 
908

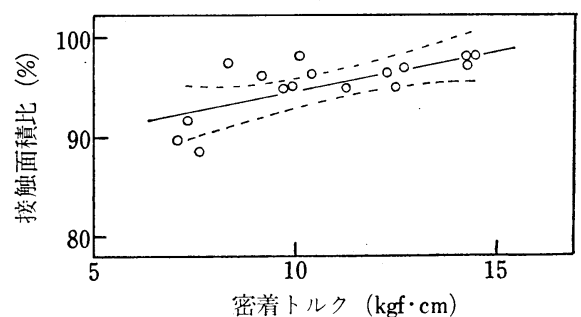

(a) 試料 $\mathrm{A}$

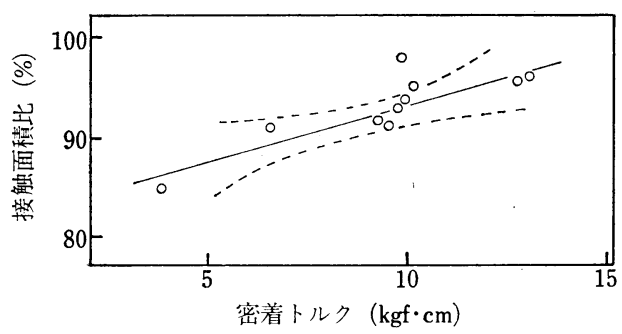

(b) 試料 B

(d) 試料 D D

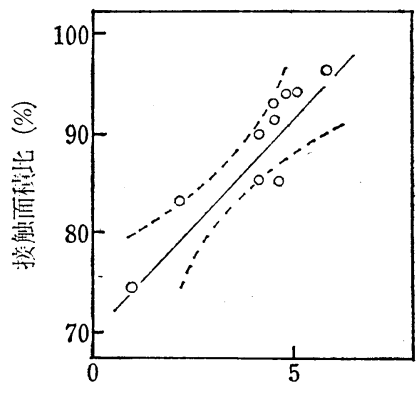

密着トルク $(\mathrm{kgf} \cdot \mathrm{cm})$

(c) 試料 C

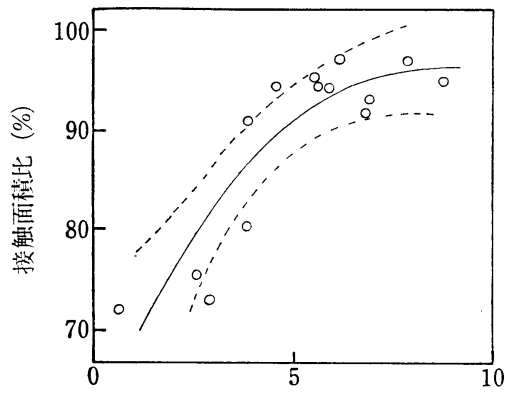

密着トルク $(\mathrm{kgf} \cdot \mathrm{cm})$
これらブロックゲー ジとガラス面を用いた 結果から推定して, ブ ロックゲージ同志を密 着した際の密着トルク および接触面積比は次 のように考えられる。

密着トルクは, 既報2〉 でブロックゲージとブ ロックゲージ相当の瞩 製定船との密着トルク がガラス定盤とのそれ より小さいことを報告 したが，これとほ注同 様な結果が得られるこ 思われる. 接触面積比 は，一般論として鋼製 のブロックゲージ面は ガラス面と比較して表 面粗さその他微視的市 形状があらく，ここでの結果より減少すると推定さう る. したがって, 接触面積比と密着トルクとの間には, 図 7 (a)〜 (d) のデータの座標を減少，つまり左下方向 へ移動し，公配を少し増大した図形が得られる之考えら れる.

\section{8. 結 論}

光電的な接触面積比に関する実験を行い，ガラス定盤 に密着されたブロックゲージの裏面からの反射光による 密着評価法は可能性が確かめられた。 すなわち接触面積 が大きくなる程密着力も増加することがわかった。これ は“密着面が互いに接近する場合程密着力が増加する” といら既報1)の結論を裏書きするものであるが，しかし 定量的に論ずるにはさらに多くの問題が残されているき のと思われる.

終わりに, 本研究のデータ処理にご援助願った計量研 究所石田一技官に謝意を表する.

\section{文献}

1) 加藤 敬：ブロックゲージの密着力と寸法誤差, 精密裁 械, 39, 4 (1973) 455 .

2) 加藤 敬：ブロックゲージの密着力と寸法誤差 (続報). 精密機械, 40, 2 (1974) 189.

3) F.P. Bowden and Taber: The Friction and Lubrication of Solid, Oxford Press, (1950) 31.

4）桜井好正：接触面積測定に関する研究，機械試娩所今 報, 6, 16 (1952) 215 .

5）桜井好正：全反射法による加工面の評価について, 精密 機械， 21，3 (1955) 89 . ベたように明快な関係は得られなかった。 